\title{
EU 政体における領域性とデモス
}

一デモイクラシーと市民の境界——

\section{土 谷岳 史}

\section{問題の所在}

EU デモクラシー論においてはいわゆる「デモス不在論」がひとつの議論の 焦点となってきた。すなわち一方に，ネーションーステートに立脚する「デモ ス」がデモクラシーに不可欠として, EUレベルでのデモスの可能性を探求す る立場, 逆に, その EUにおける不在を理由に EUデモクラシーは不可能とし て退ける立場がある。他方で,「デモス」がネーション - ステートをモデルと する必要は必ずしもないとし, 新しい形の「デモス」を追求する理論的立場も 存在する [cf. Warleigh 2003; Kohler-Koch \& Rittberger 2007; Vink 2007; 土谷 2008; Eriksen \& Fossum 2012]。この後者の中で近年活発に議論されて いるのが, 複数のデモス (デモイ) からなるデモクラシーであるデモイクラシ 一論である [Müller 2011]。

複数のデモス間の関係に注目したワイラー（J.H. H. Weiler）を参照しつつ, 「デモイクラシー」理論を展開したのがニコライディス (Kalypso Nicolaïdis) で ある。彼女のデモイクラシー論ではヨーロッパ・デモスは想定されていない。 デモスは国家と結び付いたネーションを意味する。デモスであるヨーロッパの 諸人民間の相互承認による政治がデモイクラシーなのである。

EUは多中心的でマルチレベルな統治構造を有している。EUレベルでの決 
『日本 $\mathrm{EU}$ 学会年報』第33号, 平成 25 年 4 月

定の多くが指令であり，また開放型調整方式（OMC）が積極的に活用されると き，ステート・レベルの政治の重要性は疑いえない。そうであれば, EUデモ クラシーとはステート・レベルの領域的政治の規範的再検討を含んだマルチレ ベル・デモクラシーの構想が必要であろう。デモイクラシー論は加盟国のネー ションをデモスとして明確に位置づけ，そのデモス間の関係から EU 全体を理 解しようとするという意味でマルチレベル性に自覚的な理論である。しかし， 加盟国の領域には他の加盟国の国民や第 3 国国民が存在する。ステートの政治 を担うのがネーションであると排他的に想定されるとき，EUはネーショ ン - ステートによる排除を再生産しはしないだろうか [土谷 2005；2006；バリ バール 2007]。

このデモクラシーの境界問題, 領域的排除の問題はデモクラシー理論におい て度々指摘されている [Whelan 1983; Besson 2006; Song 2012]。これまで ネーション - ステートによる排除を問題視する規範的政治理論のいくつかは, その解決方途または可能性として EUに注目している [Archbugi, Held \& Köhker 1998; Preuss \& Requejo 1998; Habermas 2001; Benhabib 2004; Besson \& Martí 2006; Bohman 2007; Archibugi, Koenig-Archibugi \& Marchetti 2012]。では, EUデモイクラシー論はこの規範的問いにどのように答 えるのだろうか。

ニコライディスは相互承認の論理の波及をみている。彼女によれば,「デモ イクラシーは他のヨーロッパ人と非 - ヨーロッパの『他者』の一貫した処遇を 要請する」[Nicolaïdis 2004: 106]。EUが多様性の中の統一というモットーを 標榜するのであれば, 経済成長から取り残された者や新規加盟国の EU 市民に 加えて, EU 域内に生きる第 3 国国民の包摂が課題となる [Nicolaïdis 2004: 108-9]。そしてデモイクラシーの精神においては相互承認の論理と包摂は外部 のパートナーにまで広げなくてはならない。このようにニコライディスは規範 を語るが, $\mathrm{EU}$ 加盟国のネーションの間で限定されていたデモイクラシーの原 理が規範理論としていかに第 3 国国民にまで及ぶのかは明らかではない。 
そこで本稿ではまず EU デモイクラシー論を本格的に展開したニコライディ スの議論をロールズの理論に依拠して発展させたシェネヴァル (Francis Cheneval）の議論と, ニコライデイスの議論を批判的に発展させたベッソン（Samantha Besson）の議論を見ていく。デモイクラシー論の主要論者である彼らはデ モイの複数性と領域的排除に対して異なるデモイクラシーの構想を提示してい る [Besson \& Martí 2006: xxi]。彼らの議論を検討することで規範的政治理 論としてのデモイクラシー論が持つ領域性と市民に関する包摂と排除の一面を 明らかにしたい。

\section{1．国家の人民と市民の二重性による公正な契約}

シェネヴァルはニコライデイスの EU デモイクラシー論を直接発展させるの ではなく, 一般的な規範理論として EUに限定されないデモイクラシー論を展 開する [Cheneval 2011: 9]。それは自由で民主的な人民の間でのデモクラシ ーである。現在の世界から出発した漸進的アプローチを標榜するシェネヴァル は，まずは自由民主主義国家間での政治的正義の実現を主張する。このため彼 はデモイクラシーを多国間デモクラシーと呼んでいるが，EUにも適用して論 じている [Cheneval 2009; Cheneval \& Schimmelfennig 2013]。ここでもデ モスは国家と結び付いたネーションである。

シェネヴァルはロールズの原初状態の議論を用いて, デモイクラシーの基本 構造となる原則を導き出す。注意すべきは, 誰が原初状態において主体となる か，である。それは国家の主権者としての「人民」と個人としての「市民」で ある。デモイクラシーは権限分配の決定権を人民に持たせる。 $\mathrm{EU}$ 諸条約の改 正には各加盟国が拒否権を持つように，主権は権限分配の変更を認めないとい う意味では各人民に保持される [Cheneval 2011：18-9］。逆に，EU 諸条約の 改正により権限分配の変更を行うには全加盟国の合意と批准が必要であるとい う意味では諸人民の集合体が主権を持つ。つまり各国は現状維持の「消極的主 
『日本 $\mathrm{EU}$ 学会年報』第33号, 平成 25 年 4 月

権」を個別に持ち, 現状を変更する「積極的主権」は加盟国に共有されるので ある。

では，人民と市民が存在するデモイクラシーの原初状態において導き出され る原則とはいかなるものであろうか。無知のヴェールの下で人民は自分たちが 大国なのか小国なのかなどを知らない。同様に市民は自分の国籍や地位，立場 などを知らない。自分自身の現実の状況から離れて合意される 7 つ原則が挙 げられる [Cheneval 2011: ch 7]。

1. 参入，離脱，及び多国間デモクラシーの政治秩序の基本ルールに関する 国家人民の構成的権力の主権

2. 国家人民と市民の差別の禁止

3.トランスナショナルな権利の相互承認

4. 市民と国家人民の代表制

5. 憲法論における垂直的抑制と均衡

6. 言語的正義の 2 原則

7.メンバーである国家人民の格差原理

第 1 原則は上述の主権の議論である。第 2 原則は条約に規定されていない権 利や便益について各国家領域内における全ての人間に適用することである。1 国において規定された権利や便益は当該国内で普遍的に適用され，相互性（reciprocity）の概念により多国間デモクラシー参加国全体へと広まっていく。第 3 原則は個人の権利と自由のトランスナショナルな次元, すなわち移民の権利で ある。自由移動の権利と政治的権利が保障される。

第 4 原則は国家代表と市民の普遍的な代表の二重の代表制を意味する。主権 の行使によって認められた権限については政府間の意思決定と超国家的議会の 意思決定が組み合わせられる。第 5 原則は憲法問題に関して超国家的高等裁判 所が加盟国の高等裁判所へのアカウンタビリティと共同決定を制度化すること である。多国間法の優越性はこれを条件として実現する。

第 6 原則の第 1 はある領域に長期居住する少数派言語集団の言語的領域性の 
承認である。第 2 に全ての加盟国の公用語が公用語として認められる。公用語 の数が多すぎる場合には共通語を定め, 語学教育の負担を分け合う。最後の第 7 原則は格差原理である。加盟国間の経済的不平等は, 多国間デモクラシーの 秩序から最も利益を受けていない国家により大きな利益をもたらす限りにおい て認められる。デモイクラシーの経済的条件では最も利益を受けない国家が最 大の利益を得る可能性を持たなければならない。

シェネヴァルの構想ではあくまで人民の自発的な主権の行使によってデモイ クラシーが成立する [Cheneval 2009: 250］。彼はデモイクラシーの原初状態 において第 3 国国民の存在を認めない [Cheneval 2011: 121-4; cf. 2009]。デ モイクラシーは相互性を要請する, すなわち信頼に足る政治的コミットメント が求められ，そしてまた自国の市民に応答する人民の相互責任も要請される [Cheneval 2011: 84, 125-6; cf. 2009: 252-3]。集団的自己決定や政府の権力, 政治構造の中での集団的政治代表への権利は個人の権利に還元できない。これ らは自由で民主的な人民の憲法に根拠を持っている。したがって民主的に構成 された集団のみが多国間デモクラシーの参照項となるのである。

しかし人民の倫理的重要性は個人の自律の保障にある。彼のデモイクラシー 論において市民は国境を越えて自由に移動することが可能な存在である。市民 は領域的に規定された人民，すなわちネーションの一員であるだけでなく，領 域を自由に移動する移民ともなる。人民は集団としての利益を考え頭脳流出な どを避けたいため，市民の移動は国家人民の利益と衝突する可能性がある [Cheneval 2009；2011：123-4]。このため人民とは区別された市民が原初状態 に呼び出されるのである。この移動の可能性を考慮に入れて市民は人民とは異 なる存在として原初状態において考え，合意する。

ただしこの市民は同時に国家人民でもある。様々な集団は人民の中に解消さ れ，他方で，デモイクラシーを構成する人民に属さない者は原初状態において 居場所を与えられない。人民の中の諸集団及び第 3 国国民の権利は，デモイク ラシーを構成する各国家がリベラルで共和主義的であることによって保障され 
『日本 $\mathrm{EU}$ 学会年報』第33号, 平成 25 年 4 月

る [Cheneval 2011: ch3]。

しかし第 3 国国民の政治参加は討議デモクラシー論の中に見出すことができ る。決定の影響を受ける者によるデモス形成という利害影響原理を否定するシ エネヴァルは 2つのデモス概念を提示する [Cheneval 2006; 2011：ch 4]。第 1 は, 形式的なメンバーシップであり, 公式の意思決定に参加する。第 2 は, 開かれた公共の討議によるデモスである。討議共同体は法的政治的共同体より も大きく，前者の中に後者は埋め込まれている。討議は普遍的なものであり， 脱領域的である。政体構築の正統性は開かれた討議に埋め込まれた手続きで表 明された仮想的意思にある。「民主的正統性は限定された政治的主体性と, 主 体中立的な共通の妥当性というこの二重性を意味する。 [Cheneval 2011：79] 当該国家に居住する外国人などの公的なデモスに属さない者による理由の提示 を公的なデモスが受け取り，討議する [Cheneval 2006: 164-5]。

シェネヴァルのデモイクラシー論は討議デモクラシー論によって普遍的な包 摂を行う。しかしこのために第 3 国国民の固有の地位は捨象され，主体性は否 定される。さらに, 政体構成の正統性が国家人民と市民の原初状態による仮想 の社会契約に存するため, EU市民と第 3 国国民の間には相互性が想定されな いだろう。原初状態の議論は EU 市民と第 3 国国民を積極的に区別する根拠と なる。そのため第 3 国国民の包捸は加盟国のデモスの決定に任されるように思 われる。

\section{2. 領域的排除とデモイクラシー}

ニコライディスの引用から始まる Besson [2006] は民主制が領域に依拠す ることによる非 - 市民の利益の排除を問題視する。そこでベッソンは，ポス ト -ナショナルな主体としてデモスの前政治性を否定し, 制度による連帯の可 能性を指摘する [Besson \& Utzinger 2007a: 638-9 9]。この連帯は領域的なも のである必要もない。国境と結び付かない様々なデモイが存在し, そしてデモ 
スは単一性を性質とする必要もない。

以上を踏まえてナショナルなデモイとヨーロッパ・デモスが区別される [Besson 2006: 188-9]。前者はヨーロッパのデモクラシーの基本となる主体で ある。EUは諸国家と諸人民の双方からなる連合である。ヨーロッパ・デモス がナショナルなデモイの総計以上のものであるにせよ, それは複数的な性質を 持っており, 各ナショナルなデモスから切り離せない。

ここでベッソンは他のデモイクラシー論と袂を分かつことになる。ニコライ ディスが主張するようにデモイクラシーが隣人の政治生活を気にかけ，互いの 声が聞き届けられるメカニズムを必要とするならば, 多くのヨーロッパのデモ イの間でのトランスナショナルな討議が規範的に要請される [Besson 2006: 192-3]。しかし，そうであるならばその討議は領域的な限定のもとでは達成さ れえないだろう。したがってナショナルなデモイが位置づけられる領域的な存 在と, 利害影響原理によって確定される, デモイからなるヨーロッパの機能的 デモスを区別しなければならない。

ニコライディスがあくまでデモスをネーションに閉じ込めたのに対して, ベ ッソンは領域的に区切られたナショナルなデモスに加えて, 非領域的な機能に よって区切られるデモスを構想するのである。これをベッソンは討議デモクラ シー論と接合する [Besson 2006: 197]。しかしシェネヴァルが主体中立的な 普遍的な討議によってデモスの一面を構想したのに対して, ベッソンはこの道 を取らない。彼女は民主的討議の範囲を決定によって重大な影響を受ける者全 てに広げるため, 選挙のまたは公式の有権者に加えて, 道徳的 - 政治的有権者 として討議を行う新たな主体を考慮する。

これがデモイクラシーの真の意味である。すなわち，互いに討議しあう 様々な領域的デモイの市民と共にそれらデモイを横断する民主的討議であ り，それによって個別の事例において異なる機能的ラインに沿うひとつの デモスを構成する。[Besson 2006: 197] これはどういうことであろうか。ベッソンは 3 つのガヴァナンス・レベルでの 
『日本 $\mathrm{EU}$ 学会年報』第33号, 平成 25 年 4 月

脱領域化を示すがここでは最初のものだけ見ておこう［Besson 2006：199； 2007: 2]。ナショナルなレベルでは, 問題領域によってナショナルなデモスと 共に他のヨーロッパ市民が討議に加わる。ナショナルな討議の場は機能的なヨ ーロッパ・デモスの討議の場となる。これが脱領域化である。

第 1 に，ヨーロッパの大文字の他者は全てのナショナルなデモイのひとつ の機能的層であるヨーロッパ・デモスの部分となる。それ自身で，彼女は 各領域的に区切られたナショナルなデモスの真の機能的市民である。例え ば，ひとりひとりのヨーロッパ市民は他のヨーロッパのどの国でも地方及 び欧州の選挙に投票し，立候補することができる。換言すれば，EUにお いて自身の政体を選択する権利があるのである。〈中略〉政体を選択する この能力と, それが当該政体に生み出す利益は, 第 2 に, 問題となるナシ ヨナルな政治過程におけるナショナルな決定によって潜在的に影響を受け る他のヨーロッパのデモイのメンバーの利害の予防的内面化につながるで あろう。[Besson 2006: 199-200]

ベッソンの機能的デモスに含まれるのはナショナルなデモスに属す EU 市民で もある個人である。ワイラーやニコライデイスとは異なり, ベッソンは相互の 直接的な参加を通じてヨーロッパの他者との関係が構築されると論じている。 互いのナショナルな諸決定が持つ相互の影響が討議における相互性の基盤とな る [Besson 2006: 198]。この構図は他の脱領域的な討議の場においてもかわ らない。

では，非-EU 市民はどうだろうか。EU 域内での第 3 国国民の社会的，政 治的諸権利の漸進的拡大傾向を認識するベッソンはそれを欧洲統合と他国の EU市民の包摂の帰結とする [Besson 2006: 202-3]。当然ながら EU 域内に居 住する第 3 国国民は EU 内のナショナルな政体とは領域的につながりを持って いる。ここでベッソンは EU 市民と第 3 国国民を並べ，EU 市民に与えられる 権利などが第 3 国国民へと拡大していく図を描いている。その結果, ナショナ ルな討議が他国の EU 市民の利害を内面化するように，第 3 国国民の利害も内 
面化すべきと論じる。そして次に EU 域外の第 3 国国民にまで広がる。 EU デ モクラシーの主体はナショナルなデモイではなく, 第 3 国国民も含んだ汎ヨー ロッパのデモスとなるのである。

「傾向」から「第 3 国国民の利害を内面化すべき」との規範が導き出される。 しかし，ある事象が生み出す効果または規範は妥当だとしても，規範的にその 事象が正当化されるかどうかは別問題である。ベッソンは脱領域的なデモイク ラシーでは公共的討議に扔ける正当化の義務の根拠をなす相互性が欠けている との批判に対して次のように反論している。

多元的な法秩序においてナショナルな決定が相互に影響を与えるというこ とが, 討議に扮いて求められる相互性の基盤を提供する。[Besson 2009a:

75]

だが, ナショナルなデモスが互いを相互性において EU 市民として認め, 政体 を構成するデモイクラシー論において，相互的ではない第 3 国国民に EU 市民 と同様に承認を与えるとの論理はいかなる理論的根拠を持つのだろうか。

ベッソンの構想で特徵的なのは機能的なデモスという概念である。シェネヴ アルと異なり，政体の構成段階を議論せず，すでに構成された EU 政体につい て論じるベッソンはナショナルなデモスにヨーロッパ・デモスの母体となる役 割しか与えていない [Besson 2007: 6; Besson \& Utzinger 2007a: 641]。ナ ショナルなデモスは影響が領域的に限定されない決定を行う場合には機能的デ モスへと変容する。デモスは制度の政治的行使によっても生み出されうると主 張するベッソンの理論では, ナショナルなデモスを核にヨーロッパ・デモスは 偏在しているのである。

ナショナルなデモスから出発したベッソンのデモイクラシー論は, ナショナ ルなデモス自体を否定せず存続させるが, 問題ごとにデモスが編制されるとい う意味で，それは 2 次的なものとなっている。決定の影響を受ける者がデモス を構成するという利害影響原理が第 1 にあり，第 3 国国民の包摂が要請される [Besson 2009a]。決定の影響範囲がネーションにとどまる限りにおいてナシ 
『日本 $\mathrm{EU}$ 学会年報』第33号, 平成 25 年 4 月

ヨナルなデモスは肯定される。しかしそうでなければ他の EU 市民や第 3 国国 民がデモスの構成に加わらねばならない。ナショナルなデモスは機能的には同 時にヨーロッパ・デモスとなる。

しかし先に見たように, 討議の基盤は意思決定する政体を基盤としたナショ ナルなデモスである。すなわちべッソンにおいても相互性は政体を基盤にして いる [cf. Besson 2007: 16]。他方で, ナショナルなデモスはネーションの外 にも影響を与える決定を行う場合には利害影響原理によって機能的デモスとな る。機能的デモスの範囲は相互性によって確定されるのではない。ここでベッ ソンのデモイクラシー論は異なる 2 つ原理に依拠していることが明らかにな る。相互性と機能的デモスはそれぞれ異なる「影響」の概念から派生している のである。一方は政体間の相互の影響（mutual influence）であり，他方はある 政体の決定が影響を与える（affected）個人の範囲である。

本稿の関心からはこの 2 つ関係が問題となろう。ベッソンのデモイクラシ 一論は機能的デモスを想定すると共に，デモス間での討議を重視する。すなわ ち, 討議の場は複数, 多中心的に存在するだけでなく, 多層的にも存在する。 普遍的な主体なきコミュニケーションではなく, それぞれの差異化された立場 からの討議が様々な場で行われる [Besson 2006: 206]。ネットワーク化され た様々な場での討議は蓄積され，次の討議がその上に重ねられることになろう [Besson 2007: 11-2]。

ベッソンは, 様々な場で議論され, 結論の一致をみない問題の存在自体にデ モクラシーの可能性を見る [Besson 2005]。相互性と機能的デモスの齟龉を 明らかにする第 3 国国民の包摂の問題はそのような問題のひとつであろう。あ る加盟国で第 3 国国民を EU 市民と同様に包摂したならば，その影響は他の加 盟国にも及ぶことになる。「ヨーロッパの立法過程では，様々な権威によって 反復的に同じ決定がされる」が, これは EUレベルでの決定を各加盟国で執行 することにとどまらない。水平的なヨーロッパ化や下からのヨーロッパ化も起 こる。すなわち，ある場での機能的デモスの具現化は「互いの規範的秩序に相 
互に影響を与える」ことになろう [Besson 2007: 13, 15; cf. Besson \& Utzinger 2007a; 2007b; 2008]。

国籍国以外で欧州議会選挙と地方選挙に参加する $\mathrm{EU}$ 市民に対して, 第 3 国 国民がなぜ同じ権利を持たないのかとの疑問は当然というベッソンの認識は [Besson \& Utzinger 2007a: 636], 利害影響原理之は次宇を異にするももの゙ ある。ベッソンの議論では，EU 域内に居住する第 3 国国民は EU シティズン シップの影響によって居住を基準に政治的メンバーシップが与えられるべきと される [Besson \& Utzinger 2008]。

機能的デモスのあり方自体が多層化，多中心化されたデモイの中で，間で, そしてデモイを横断して議論されることで反省性がより発揮され，相互性のい わばエートスは第 3 国国民を含めたヨーロッパ全体へと，そしてヨーロッパを 越えて広がっていく，このような構図をベッソンは構想しているように思われ る [cf. Besson 2006: 206; 2007: 13, 15; 2009b: 234-6; 2012: 332-3; Besson \& Utzinger 2007a: 639-40]。利害影響原理がデモイクラシーの構造によって討 議の蓄積の中で反省的に波及し， EU 市民間の相互性が第 3 国国民にまで及ん でいくことで汎ヨーロッパ・デモスが形成される。すなわちデモイクラシーは 既存のネーション - ステート・デモクラシーによって排除される者の包摂を促 す反省的メカニズムなのである。だが，それは EU市民間の相互性を第 3 国国 民に拡張すべきとの明確な正当化の根拠を与えてはいない。

\section{3 . 第 3 国国民を包摂するデモイクラシーへ}

デモイクラシー論は EU の現実を規範的に解釈する強力な理論と言えるだろ う。EUの条約は加盟国の合意と, 全加盟国の批准が必要という意味で, ネー ションが決定権を握っている。条約制定は EU 市民全体の投票によって決めら れるわけではない。確かに憲法制定権力を持つようなヨーロッパ大の単一のデ モスは存在しない。しかし，個人はネーションの一員であると同時に EU 市民 
『日本 $\mathrm{EU}$ 学会年報』第33号, 平成 25 年 4 月

でもある。EU市民であることの恩恵の多くは加盟国レベルに制度に依拠して いる [土谷 2006]。EUの中心にはネーション - ステートがあるが，それは相 互承認という形で互いに開かれている。デモイクラシー論は EU の特異性を的 確に反映しているだけでなく，より積極的に評価するのである。

しかし，ネーションの重要性を強調するほどにネーション - ステートに基づ くデモクラシーの排除を再生産する危険性が高まる。第 3 国国民の包摂につい てニコライディスはいわば寛容のエートスの拡大を主張するが，デモイクラシ 一論からそれがどのように正当化されるのかは不明確であった。

シェネヴァルは原初状態の議論を用いてデモイクラシー論を展開するが, 原 初状態から第 3 国国民を排除してしまう。一面では現在の EUをより現実主義 的に正当化するが，利害影響原理を否定しナショナルなデモスを維持すること で，相互性から排除された第 3 国国民は固有の立ち位置を与えられず，普遍的 な討議のデモスに含まれる。しかし討議デモクラシー論による脱領域的な包摂 は，第 3 国国民を排除した原初状態による政体の正統化によって限界づけられ ることとなろう。

これに対してベッソンは利害影響原理によって第 3 国国民を包摂する。しか しデモイクラシーが依拠する EU 市民間の相互性がなぜ第 3 国国民に拡張され るべきなのか不明確である。デモイクラシーは各デモスでの包摂についてのよ り強固な反省的メカニズムにとどまり，2 次的な原理となっている。さらにべ ッソンの理論では第 3 国国民の包摂について域内と域外の理論的な区別が明確 ではない。居住に基づき第 3 国国民に政治的メンバーシップを付与すべきとし つつ, EU シティズンシップなどの居住という領域的つながりが脱領域的なも のと解釈されるからである [cf. Besson 2006: 199-203]。主体としての人民と 主権者としての人民を一致させる基準の発見が課題とされるものの, 規範的な 影響原理の基準が答えとして历めかされるのみである [Besson \& Utzinger 2007a: 643-4]。

ナショナルなデモスを領域的政体としてその相互承認や相互性に依拠するデ 154 
モイクラシー論はステートという領域の位置づけが不明確であるように思われ る。ステートの住民とネーションのずれは理論的に解決されていない。シェネ ヴァルもベッソンもデモイクラシーの問題はまずナショナルなレベルにあると している [Cheneval \& Schimmelfennig 2013; Besson 2009a: 83]。しかしこ れはネーションとステートの関係を今一度デモイクラシー論において問い直す 必要性として解釈されねばならないだろう。デモイクラシーの核となる領域た るステートを今一度理論の中に位置づけ，第 3 国国民と EU 市民との相互性を 再考するべきである。

$\mathrm{EU}$ 市民の自由移動の権利をベッソンが政体選択として解釈するならば，第 3 国国民が EU 域内に移動してきたこと自体がまさに政体選択の実践である。 また移民の 2 世以降は基本的に移動しておらず，その社会のなかで生まれ育っ た事実上の成員である。ニコライディスの言うように EUが「プロジェクトの 共同体」であるならばそのデモスに第 3 国国民が含まれないことは不当な排除 であろう [Nicolaïdis 2001: 473; 2003: 146]。

ベッソンの議論に沿ってデモイクラシーを考えると, 機能的デモスを考える 際に初期条件のデモスをいかに設定するかという問題である。ベッソンはこれ をネーションにしているが, 同時に居住も重視している。問題は居住という領 域的つながりを脱領域的つながりとして解釈することにある。確かに領域的つ ながりを排他的に領域性に限定する必要はない。それは例えば，移民と本国の 関係といった脱領域的つながりを見失うことにもなりかねない。機能的ヨーロ ッパ・デモスが遍在するベッソンの議論において領域的／非領域的つながりは 相互排他的ではない。しかしベッソンの場合は逆に，脱領域性を強調するあま り, 領域的つながりの重要性が見過ごされている。

$\mathrm{EU}$ において機能的デモスを考えてみると， OMC や権利保障のあり方など, その核となるのは多くの場合, 依然として領域である [土谷 2006]。すなわち 利害影響原理によってデモスを機能的に考えると，ステートという制度を共有 することが規範的基準となる。あるステート内に定住する第 3 国国民と EU 市 
『日本 $\mathrm{EU}$ 学会年報』第33号, 平成 25 年 4 月

民の間にはステートという制度を介した恒常的な相互性が存在する。したがっ て初期条件としての機能的デモスはナショナルなデモスではなく, ステートの 居住に基づくデモスと考えるべきである。ベッソンが検討しているように，こ の居住を基準にしたデモスへの有力な包摂方法には居住を基準としたシティズ ンシップ付与や居住を基準とした帰化の容易化がある。

ここでシェネヴァルの議論を思い出そう。彼の議論では, EU 領域内を移動 する潜在的移民としての EU 市民が視野に入っていた。しかし第 3 国国民は原 初状態から排除されていた。だが EUはすでに第 3 国国民に対して「長期居住 者」の地位と権利をはじめ様々な $\mathrm{EU}$ 法で直接かかわっている [土谷 2005]。 しかもこれら第 3 国国民の地位には EU 域内を合法的に自由移動できる権利が 含まれている。すなわち $\mathrm{EU}$ 加盟国へ移民してきた第 3 国国民はまた，EU市 民と同様に EU 域内を移動する潜在的移民でもある。彼らが EU 域内での移動 を繰り返すとすれば, 特定の EU 加盟国への帰化というベッソンの提案は第 3 国国民を十分に包摂できない危険性を持つ。領域を考える場合，すでに EU の 現実はステートにとどまらない領域としての EUを考えることを要請する。シ エネヴァルのようにリベラルで民主的な加盟国に第 3 国国民の包摂を期待する だけでは不十分なのである。移民は一方的に移動してくるのではなく, 植民地 支配の過去や受け入れ国の決定に強く影響を受ける。EU と加盟国が民主的で あることを自認するのならば，少なくとも定住第 3 国国民の排除は自らの民主 制を掘り崩すことになる。帰化に限定されない居住加盟国における十分な権利 保障が求められる。

問題は, ベッソンのデモイクラシー論が構想する相互性に基づく反省的均衡 による包摂が十分に発揮されるかであろう。危機にある現在の EUでは第 3 国 国民を排除する傾向が強まっている。さらに言えば，金融危機を受けて相互性 に基づく EU 市民間の関係もその脆さを露呈している。この点を鑑みるとシェ ネヴァルの議論は有用であろう。シェネヴァルの議論を修正し, 原初状態に第 3 国国民も参加させることで，EU が依拠すべき原則に第 3 国国民の立場が反 
映される。人民と市民が完全に一致する必要はない。人民と市民が一致すると の想定は, デモイクラシー論の革新性の主張とは裏腹に, ネーション - ステー ト・モデルをいまだ引きずった思考様式であろう。

各加盟国での第 1 の契約の後に EU を設立する第 2 の契約を考えよう。第 2 の契約を結ぶための原初状態には，加盟国の主権者としての人民，潜在的移民 としての $\mathrm{EU}$ 市民に加え，EUへの移民を選択した第 3 国国民，EU 域内の定 住第 3 国国民，EU 域内の潜在的移民としての第 3 国国民が参加する。参加者 はこのような多様な立場・地位・利害の違いを認識しているが, 無知のヴェー ルをかぶっており，自分がどのような存在なのかは知らない。その結果，第 3 国国民に対してより包摂的な原理が選択される。

この原初状態論が EU の統制的理念として機能することで, $\mathrm{EU}$ 市民間の対 立のみならず，第 3 国国民に対する排除へのより強固な批判が可能になろゔ。 ベッソンの提示する機能的デモスとも両立する構想であるだけでなく, むしろ 機能的デモスをより実効的にするだろう。シェネヴァルが強調する政体による 主権の行使という論点に関しても，第 3 国国民も含めた EU 全体での全住民に よる投票や各国別での全住民の投票による $\mathrm{EU} の$ 再承認や条約改正は十分に構 想可能である。これもまた現実主義的ユートピアであり，シェネヴァルが暗黙 裡に想定し, ベッソンが明示的に求める $\mathrm{EU}$ 域外に開かれたデモイクラシーの 実現でもある。原初状態に含まれる第 3 国国民は国籍国や出身国とのつながり を持っている。 $\mathrm{EU}$ 域外の人々からの規範的主張に対する応答責任は $\mathrm{EU}$ 域内 の第 3 国国民の存在により一層強く意識される。このように制度を共有する 人々がデモイクラシーにおいて相互の規範的応答に互いに応えていく中で理念 的な機能的デモイが実質を獲得していく過程を想定できる［齋藤 2008: 63； Habermas 2012: 46-9]。 
『日本 $\mathrm{EU}$ 学会年報』第33号, 平成 25 年 4 月

\section{結 論}

本稿ではデモクラシーの境界問題, すなわち EU における第 3 国国民の排除 の観点からデモイクラシー論の批判的分析を行った。シェネヴァルの議論では, 普遍的討議に第 3 国国民は包摂されるものの，原初状態からは第 3 国国民が排 除されていたため, より深刻な排除の危険性を指摘した。これに対してベッソ ンの議論では利害影響原理によって第 3 国国民が包摂されていた。しかし彼女 の機能的デモスの構想はデモスの脱領域化を強調するあまりデモスの境界の不 確定性が際立つものとなっていた。この両者の議論に共通する問題は, ステー トとネーションの混同にあることを指摘した。

そこで本稿ではベッソンの議論を受けつつ, 共通の制度の基盤となるステー トという領域を基準としてデモクラシーの成員を確定することを提案した。 $\mathrm{EU}$ 市民と第 3 国国民の間にはステートを基盤に相互性が存在するのである。 さらにシェネヴァルの議論を修正し, 彼の原初状態論の視野に入れた移民とし ての市民は第 3 国国民にも準用されるべきことを主張した。彼の原初状態論を 第 3 国国民も含むものとして修正することで，機能的デモスに基づくデモイク ラシーは, $\mathrm{EU}$ 域内での第 3 国国民の包摂だけでなく， $\mathrm{EU}$ 域外にもより開か れた構想となるのである。

［付記］本稿は，日本 EU 学会第33回（2012年度）研究大会での報告を基にしたもの である。司会の労を取ってくださった久留米大学の児玉昌己会員に感謝する。熟江義 勝会員 (同志社大学), 原田徹会員 (駒沢女子大学), 坂本進会員 (元早稲田大学) か らは貴重な質問を頂いた。草稿の段階で, 早稲田大学大学院の上原賢司, 田畑真一, 内田智, 岸見太一の各氏拉よび柴田寛之氏（ニューヨーク市立大学大学院センター） から貴重なコメントを頂戴した。記して感謝したい。有益なコメントを頂いた 2 名の 匿名の査読者にも感謝する。 
1）本稿ではネーション（国民）とステート（国家）が自然な結びつきではなく，歴史的な偶然 によること, したがって両者を一体のものとして理解すべきでないことを強調するために「ネ ーション - ステート」とカタカナの両単語をハイフンでつなぐ表記法を使用する。

2）邦語の EU デモクラシー研究には例えば， EUの多元主義的デモクラシーを提案する遠藤 [2001］やナショナルなレベルでの討議の重要性を説く鈴木［2006］があるが, デモスの問題 には触れられていない。討議デモクラシーの観点から EU に着目する篠原一の一連の研究にお いてもデモス問題はほとんど触れられてはいない [2004；2007；2012]。ただし篠原 [2007] がベッソンらのデモイクラシー論の刊行を新しい議論の展開として数行にわたり言及している のは慧眼である。よりデモス問題やデモイ問題に触れたものとして例えば, 安江 [2007], 浅 見［2005］があるが，制度論に主眼を置く前者は文化的アイデンティティと政治的アイデンテ イティの関倸についての考察の必要性と EUによる上からのアイデンティティ形成の可能性を 指摘するにとどまっている。後者はニコライデイスのデモイクラシー論に言及し, 討議民主主 義的デモイクラシーの可能性を指摘した極めて早い研究であるが, それゆえに理論的な考察は 深められていない。すなわち邦語研究に扔いては極めて先駆的な着目はあるものの, デモス問 題やデモイクラシー論に関する本格的な研究は管見の限り存在しない。

3） EUの実態は政策分野ごとに多様であり，中央集権的な分野も存在する。またそのような分 野では EU 法の優越性と司法管轄権を鑑みれば垂直的権力関係が強く存在するが, 本稿での $\mathrm{EU}$ 像は理念型としてある程度受け入れられている。さらにソブリン債危機を受けさらなる統 合の深化を先行的に進めるユーログループの存在は, 領域的な中央一周辺関係が再構成されつ つあるEUの姿を象徴している。この変化する EUを受けた理論的検討は他日を期したい。

4）共和国は道徳的人格からなる共同体の「市民」であり，国際社会における第 2 種の市民であ る。「人権またはコスモポリタンな権利は人類の政治的共同体の概念と直接は関係しない。む しろ，共和国からなるひとつの共同体に関連するのである。そこでは共和国が全ての人間個人 に対して権利と義務を承認し，その承認は協定や憲章及び国内の執行システムによって確立さ れる。」Cheneval 2009: 253；2011：53] またリベラルの「仮想契約の規範的装置は個別の政 体と個別の政治的主体性に普遍性を持ち込むトロイの木馬である。」 [Cheneval 2006: 172]

5 ） ベッソンは自身のデモイクラシー論をグローバルな政治にも適用している [Besson 2009a; 2009b]。

6） EU シティズンシップは加盟国の国籍を持つ者に諸権利を付与するものであるが，ある加盟 国の領域内での権利を当該加盟国の国籍所有者に限定するという排他的，一元的構造を動摇さ せ，ナショナルなシティズンシップの諸権利の獲得基準を国籍から居住へと移している [Besson \& Utzinger 2007a: 636-9; 2007b: 589; 2008; cf. 土谷 2006]。

7 ） ベッソンは決定に影響を受ける者全ての直接の参加は必ずしも必要とされないとする。決定 に影響を与えるべき根拠は基本的利害，自己発展または自己決定に関する利害に限定され，間 接的な参加と代表でデモイクラシーは実現されえるとする [Besson 2009a; 72-3, 81-2]。また 彼女はこの基本的利害を共和主義的自由, すなわち支配の不在としての自由と関連させて論じ ている [Besson 2009b: 235; cf. 2012]。シェネヴァルの主張とは異なり, 討議を行う道徳的 な有権者と決定する政治的な有権者との分割は人為的なものである。討議と意思決定過程をき 
『日本 $\mathrm{EU}$ 学会年報』第33号, 平成 25 年 4 月

れいに分けることはできない [Besson 2006: 193]。討議と意思決定の間の距離がむしろ利点 であり得ることを強調しつつ, 具体的な制度としてベッソンは自身を他者の立場に置くことで 非 - 市民の利害も反映させる「反省的代表」などを提案している [Besson 2006: 198, 204-5; 2009b: 231-3]。

8 ）これはナショナルなシティズンシップの変容でもある。これを捉えるベく, ベッソンらは $\lceil\mathrm{EU}$ シティズンシップ」と区別して「ヨーロッパ・シティズンシップ」の概念を提示する [Besson \& Utzinger 2007a; 2007b; 2008]。

9 ）ベッソンらは第 3 国国民の包摂方法として居住と統合に基づく帰化を提案している。しかし これは領域に基づくものであり, 脱領域的な機能的デモスの必要性とは次元を異にする [Besson \& Utzinger 2007a: 640, 644; 2007b: 581-2；2008: 198, 201]。EU 域外の第 3 国国民につ いてはその他の方法を提案している。注 7 を参照。

10）ベッソンは EU シティズンシップはいまだ「方法論的領域主義」に従っているとも評価して 機能的デモスの実現を主張していることからも曖昧さがわかる [Besson \& Utzinger 2007a: 642-3]。

11） EU シティズンシップは居住に基づくべきとの提案が繰り返しなされている。また機能的デ モスの問題点として境界の安定性があるが, ナショナルなデモスよりも居住に基づく領域的デ モスの方が安定性は高まるだろう。

12） EU は欧州人権レジームと密接なつながりを持つことを考えても，このデモイクラシーの構 想からいわゆる「不法移民」が排除されるべきではないだろう。

13）移動を考慮に入れた帰化も考えうるが，帰化以外の方法の方がより現実的だろう。

14）「不法移民」や短期居住者, 定住者などの第 3 国国民の具体的な地位や権利保障, ローカル, ナショナル，EUなどの場に扔ける政治的権利などは一義的には定まらないが，このデモイク ラシーの構想において反省的に決定される。ベンハビブ（Seyla Benhabib）の言葉を借りれ ば「民主的反復」が行われよう [Benhabib 2004]。注 7 で言及したベッソンの提案は参考に なるが，「討議を始める権利」は普遍的に認められなければならないだろう [Bohman 2007]。

15）実際の EU 諸条約の改正と統制的理念としての原初状態論および第 2 の契約を混同してはな らない。契約論は常に仮想である。注 4 も参照。

16）原初状態論を用いた国家を超えるデモイクラシーの構想は EU のような超国家的政体に適合 的なものである。しかしベッソンが構想するように各国レベルで他のデモスに開かれた民主制 の実現がグローバルなデモイクラシーの第 1 の課題とすれば, EU デモイクラシーによる包摂 の強化は EU 加盟国の民主制の質を高め, グローバル・デモイクラシーの実現に資するものと なろう [Besson 2009a]。

\section{参考文献}

Archbugi, Daniele, David Held \& Martin Köhker eds., 1998, Re-imaging Political Community: Studies in Cosmopolitan Democracy, Polity Press.

Archibugi, Daniele, Mathias Koenig-Archibugi \& Raffaele Marchetti eds., 2012, Global Democracy: Normative and Empirical Perspectives, Cambridge University Press. 
浅見政江 2005 「EU の民主的ガヴァナンスと市民」田中俊郎・庄司克宏編『EU と市民』慶應義 塾大学出版会。

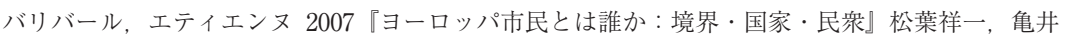
大輔訳，平凡社。

Benhabib, Seyla, 2004, The Rights of Others: Alien, Residents, and Citizens, Cambridge University Press.

Besson, Samantha, 2005, The Morality of Conflict: Reasonable Disagreement and the Law, Hart Publishing.

- 2006, 'Deliberative Demoi-cracy in the European Union: Towards the Deterritorialization of Democracy', in Samantha Besson \& José Luis Martí eds., Deliberative Democracy and its Discontents, Ashgate.

- 2007, 'Europe as a Demoi-cratic Polity', Retfaerd - Juridisk Tidskrift, 1/116.

- 2009a, 'Institutionalising global demoi-cracy', in Lukas H. Meyer ed, Legitimacy, Justice and Public International Law, Cambridge University Press.

- 2009b, 'Ubi Ius, Ibi Civitas: A Republican Account of the International Community', in Samantha Besson \& José Luis Martí eds., Legal Republicanism: National and International Perspectives, OUP.

- 2012, 'The Right to Have Rights: From Human Rights to Citizens' Rights Back', in Marco Goldoni \& Christopher McCorkindale eds., Hannah Arendt and the Law, Hart Publishing.

Besson, Samantha \& José Luis Martí, 2006, 'Introduction', in Samantha Besson \& José Luis Martí eds., Deliberative Democracy and its Discontents, Ashgate.

Besson, Samantha \& André Utzinger, 2007a, 'European Citizenship Across Borders', in Astrid Epiney, Marcel Haag \& Andreas Heinemann eds., Challenging Boundaries, Festschrift für Roland Bieber, Nomos.

- 2007b, 'Future Challenges of European Citizenship - Facing a Wide-Open Pandora's Box', European Law Journal, Vol. 13, No. 5.

— 2008, 'Toward European Citizenship', Journal of Social Philosophy, Vol. 39, No. 2.

Bohman, James, 2007, Democracy across Borders: From Dêmos to Dêmoi, The MIT Press.

Cheneval, Francis, 2006, 'The People in Deliberative Democracy', in Samantha Besson \& José Luis Martí eds., Deliberative Democracy and its Discontents, Ashgate.

- 2009, 'Multilateral Dimensions of Republican Thought', in Samantha Besson \& José Luis Martí eds., Legal Republicanism: National and International Perspectives, OUP.

-2011, The Government of the Peoples: On the Idea and Principles of Multilateral Democracy, Palgrave.

Cheneval, Francis \& Frank Schimmelfennig, 2013, 'The Case for Demoicracy in the European Union', Journal of Common Market Studies, vol 51, No. 2.

遠藤乾 2001 「ポスト・ナショナリズムに㧍ける正統化の諸問題」『年報政治学』2001。 
『日本 $\mathrm{EU}$ 学会年報』第33号, 平成 25 年 4 月

Eriksen, Erik Oddvar \& John Erik Fossum eds., 2012, Rethinking Democracy and the European Union, Routlegde.

Habermas, Jürgen, 2001, The Postnational Constellation: Political Essays, The MIT Press.

Habermas, Jürgen, 2012, The Crisis of the European Union: A Response, Polity Press.

Kohler-Koch, Beate \& Berthold Rittberger eds., 2007, Debating the Democratic Legitimacy of the European Union, Rowman \& Littlefield.

Müller, Jan-Werner, 2011, 'The Promise of 'Demoi-Cracy': Democracy, Diversity, and Domination in the European Public Order', in Jürgen Neyer \& Antje Wiener eds., Political Theory and the European Union, OUP.

Nicolaïdis, Kalypso, 2001, 'Conclusion: The Federal Vision Beyond the Federal State', in Kalypso Nicolaïdis \& Robert Howse eds., Federal Vision: Legitimacy and Levels of Governance in the United States and the European Union, OUP.

-2003, 'Our European Demoi-cracy: Is this Constitution a third way for Europe?', in Kalypso Nicolaïdis \& Stephen Weatherill eds., Whose Europe? National Models and Constitution of the European Union, OUP.

-2004, “'We, the Peoples of Europe ...”, Foreign Affairs, Vol. 83, No. 6.

Preuss, Ulrich \& Ferran Requejo eds., 1998, European Citizenship, Multiculturalism, and the State, Nomo.

篠原一 2004 『市民の政治学』岩波書店。

篠原一 2007 『歴史政治学とデモクラシー』岩波書店。

篠原一編 2012 『討議デモクラシーの挑戦』岩波書店。

Song, Sarah, 2012, 'The Boundary Problem in Democratic Theory: Why Demos Should be Bounded by the State', International Theory, Vol.4, No.4.

鈴木一人 2006 「グローバル化時代に抢ける政治的正統性」『年報政治学』2006-II。

土谷岳史 $2005 「 \mathrm{EU}$ と民主的シティズンシップ—第 3 国国民の包摂を中心に一」」曰日本 $\mathrm{EU}$ 学会年報』第25号。

—2006「EU シティズンシップとネイションーステート——セキュリティ, 平等, 社会的連帯 —」『慶應法学』第 4 号。

—2008「国際社会とシティズンシップ——EU シティズンシップの政治学」大賀哲・杉田米行 編『国際社会の意義と限界』国際書院。

安江則子 2007 『欧州公共圈：EU デモクラシーの制度デザイン』慶應義塾大学出版会。

Vink, Edwin, 2007, 'Multi-level Democracy: Deliberative or Agonistic? The Search for Appropriate Normative Standard', Journal of European Integration, Vol.29, No. 3.

Warleigh, Alex, 2003, Democracy in the European Union, Sage.

Whelan, Frederick G., 1983, 'Democratic Theory and the Boundary Problem', in J. Roland Pennock \& John W. Chapman eds., Liberal Democracy, New York University Press. 